\title{
Ascending marine particles: Significance of transparent exopolymer particles (TEP) in the upper ocean
}

\author{
Kumiko Azetsu-Scott ${ }^{1}$ \\ Ocean Sciences Division, Department of Fisheries and Oceans, Bedford Institute of Oceanography, P.O. Box 1006, \\ Dartmouth, Nova Scotia, Canada B2Y 4A2
}

\section{Uta Passow}

Alfred-Wegener Institute for Polar and Marine Research, 27570 Bremerhaven, Germany

\begin{abstract}
The high abundance of transparent exopolymer particles (TEP) in marine and freshwater greatly affects particle dynamics. TEP act as glue for colliding particles and form the matrix in aggregates, thereby altering aggregation dynamics. We studied the sinking behavior of freshly produced, particle-free TEP and of aggregates composed of TEP and latex spheres in a laboratory using water collected from Santa Barbara Channel, California. Particle-free TEP ascend and accumulate in the surface layer of a settling column at an average velocity of $1.6 \times 10^{-4} \mathrm{~cm} \mathrm{~s}^{-1}$. The estimated density of TEP ranges from 0.70 to $0.84 \mathrm{~g} \mathrm{~cm}^{-3}$. TEP also transported latex spheres of 45.6 and $1.82 \mu \mathrm{m}$ in diameter and a density of $1.05 \mathrm{~g} \mathrm{~cm}^{-3}$ to the surface layer. We describe a simple model illustrating the role of TEP for the vertical transport of solid particles. The densities and relative proportions of TEP, solid particles, and interstitial water within an aggregate determine its sinking or ascending velocity. High ratios of TEP to solid particles retard the sinking of aggregates, prolonging their residence time in the surface ocean. Our results demonstrate that TEP can provide a vehicle for the upward flux of biological and chemical components in the marine environment, including bacteria, phytoplankton, carbon, and reactive trace elements.
\end{abstract}

Transparent exopolymer particles (TEP) are important for many aspects of particle dynamics in aquatic systems. This stems from their central role in coagulation (Passow et al. 1994; Jackson 1995; Logan et al. 1995) and sedimentation of particles (Passow et al. 2001). TEP are formed abiotically from dissolved precursors released by phytoplankton and bacteria (Passow 2000) and consist predominantly of surface-active polysaccharides (Mopper et al. 1995; Zhou et al. 1998). TEP are extremely "sticky" (Dam and Drapeau 1995; Logan et al. 1995; Engel 2000) and readily form aggregates of all sizes with ambient solid particles such as bacteria, phytoplankton, molts, mineral clays, or detritus (Alldredge et al. 1993). TEP exist as microaggregates of tenths of micrometers (Simon et al. 1990) and as an integral part of snow-sized aggregates of $>500 \mu \mathrm{m}$ (Alldredge et al. 1993).

Marine particulate matter settles to great depths as snowsized aggregates (Knauer 1991). Sinking velocities of diatoms embedded in snow-sized aggregates are generally very fast (50-200 $\mathrm{m} \mathrm{d}^{-1}$; Asper 1987; Alldredge and Gotschalk 1988) compared with those of individually sinking cells ( $<1-10 \mathrm{~m} \mathrm{~d}^{-1}$; Culver and Smith 1989), allowing aggregated particles to reach the deep ocean more effectively. Factors determining sinking velocities of aggregates include size, dry weight, porosity, and excess density of aggregates (Alldredge and Gotschalk 1988), as well as density gradients in

\footnotetext{
${ }^{1}$ Corresponding author (azetsu-scottk@mar.dfo-mpo.gc.ca).

Acknowledgments

We thank Chris Gotschalk for help with the sampling, Bill Li and Karen Saunders for their help with the analyses of latex spheres, and Alice Alldredge, Dave Scott, and Christopher Cogan for comments and discussions. This work was partly supported by the Panel on Energy Research Development.
}

the water (Alldredge and Crocker 1995; MacIntyre et al. 1995) and turbulence (Shanks 2002). The density of aggregates is a function of the presence of gas enclosures (Riebesell 1992), the density of the enclosed solid matter (Asper 1987; Azetsu-Scott and Johnson 1992), and the TEP to cell ratio (Engel and Schartau 1999). The present study evaluates in detail the effect of TEP on the density and sinking velocity of aggregates.

The sinking behavior of particle-free TEP and of aggregates composed of latex spheres and TEP was investigated to better understand the transport of solid particles and substances sorbed to TEP in aquatic systems. We present experiments showing that particle-free TEP are positively buoyant, and we provide the first estimates of TEP density. The volume fraction of TEP required for aggregates to be neutrally buoyant was estimated for different solid particle types. The effect of TEP on the flux of solid particles, as well as on the biogeochemical cycles of elements associated with TEP, is also discussed.

\section{Materials and methods}

Seawater was collected in the Santa Barbara Channel $\left(34^{\circ} 20^{\prime} \mathrm{N}, 119^{\circ} 50^{\prime} \mathrm{W}\right)$ from the chlorophyll $a(\mathrm{Chl} a)$ maximum (0-20 m) for 10 different experiments in March, April, and May 1997 (Table 1). Chl $a$ concentrations at the sam-

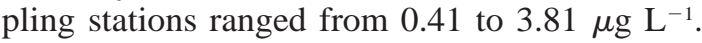

All experiments were conducted with freshly collected water. Samples were prefiltered through $0.2-\mu$ m polycarbonate (Nuclepore) filters to remove all particles, including preexisting TEP. Then, clean (particle-free) TEP was generated from dissolved precursors by rotating 1.2 liters of the prefiltered seawater in a Couette flocculator (at a shear rate of 


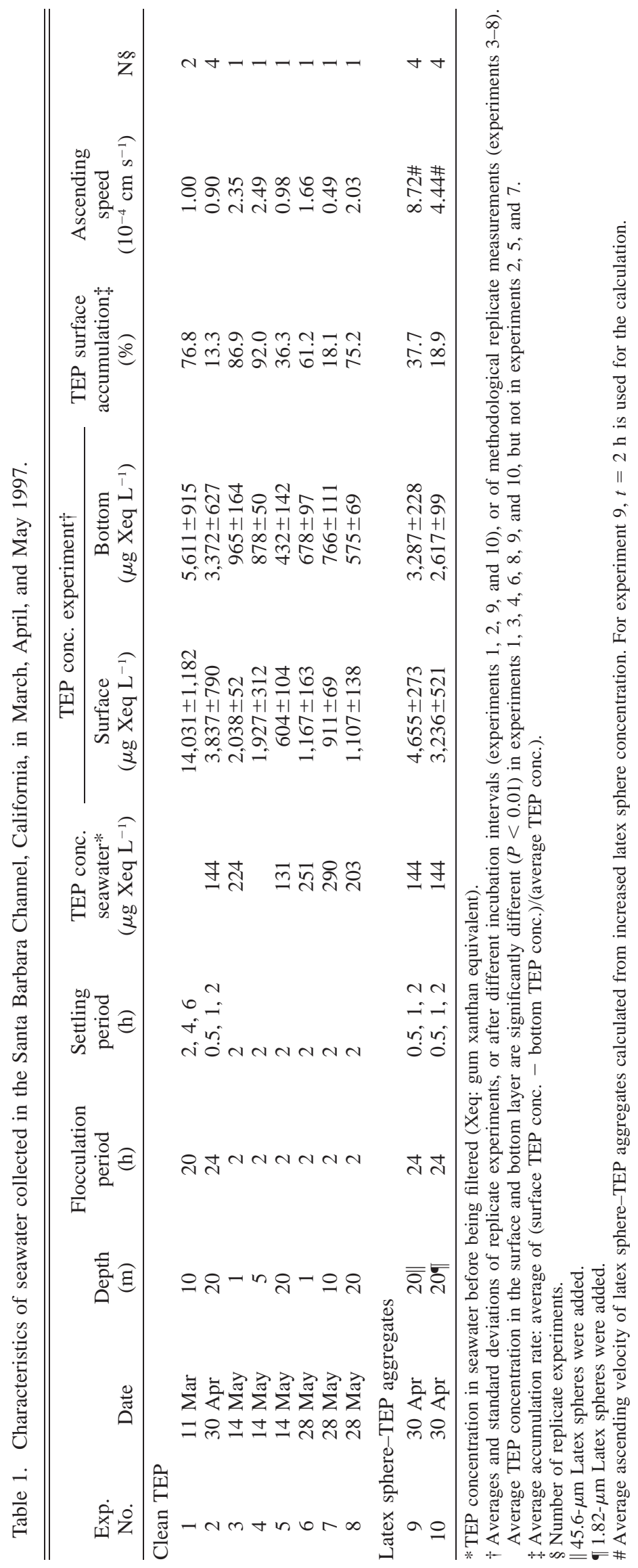


$24.9 \mathrm{~s}^{-1}$ ) for $2-24 \mathrm{~h}$ (Passow 2000). Four hundred milliliters of this water, rich in clean TEP, was gently transferred to $500-\mathrm{ml}$ polyethylene settling columns $(7 \mathrm{~cm}$ in diameter, 1 4 replicates). The remainder of the TEP-rich solution was used to determine the initial concentration and the average size of TEP. Samples in settling columns were allowed to settle for 0.5-6 h. Three 90-ml subsamples were taken from the bottom layer (bottom $300 \mathrm{ml}$ ), and two 40-ml subsamples were taken from the surface layer (top $100 \mathrm{ml}$ ) to measure the final concentration of TEP. In experiment 1, a larger settling column was used, and the surface layer was $700 \mathrm{ml}$ and the bottom layer was $400 \mathrm{ml}$, respectively. All samples were carefully drawn through a collecting tube located at the bottom of each settling column, so that vertical mixing of bottom and surface layers during sampling was minimal (Azetsu-Scott and Johnson 1992). In each step of the experiments, the introduction of bubbles was avoided to minimize the resulting production of TEP by surface coagulation. Flocculation periods, sampling intervals, and number of replicates for all experiments are summarized in Table 1.

Latex spheres (styrene divinylbenzene, Polysciences Inc.), with a mean diameter of $45.6 \mu \mathrm{m}(6.6 \mu \mathrm{m} \mathrm{SD})$ and $1.82 \mu \mathrm{m}$ $(0.31 \mu \mathrm{m} \mathrm{SD})$ and a density of $1.05 \mathrm{~g} \mathrm{~cm}^{-3}$, were introduced into the flocculator of experiments 9 and 10 to mimic the presence of small particles like diatoms or bacteria. Latex spheres were added only during the last hour of flocculation to discourage them from aggregating with each other rather than with TEP. Concentration of latex spheres was $3.4 \times 10^{6}$ $\mathrm{L}^{-1}$ for the large spheres and $4.7 \times 10^{5} \mathrm{~L}^{-1}$ for $1.82-\mu \mathrm{m}$ spheres. These values lie within the range of cell numbers of diatoms and bacteria in the upper ocean.

The concentration of TEP was determined colorimetrically by filtering samples through $0.4-\mu \mathrm{m}$ polycarbonate filters under low vacuum $(150 \mathrm{~mm} \mathrm{Hg})$ and then staining with Alcian blue. Stained TEP was redissolved in $80 \%$ sulfuric acid, and absorption at $787 \mathrm{~nm}$ was measured (Passow and Alldredge 1995). Presented results are averages of triplicate (bottom layer) and duplicate (surface layer) determinations for experiments 3-8 and averages of two to four replicate settling experiments, each with triplicate determinations for experiments 1, 2, 9, and 10. TEP data are expressed as standardized gum xanthan equivalents $\left(\mu \mathrm{g}\right.$ Xeq L $\left.{ }^{-1}\right) \pm 1$ SD. TEP concentrations in the sample water before filtering ranged

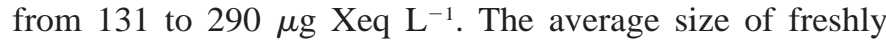
formed TEP was determined microscopically, and filters were prepared by the filter-freeze transfer method (Passow and Alldredge 1994). Concentration of latex spheres was measured with a Coulter Counter (Multisizer II) for 45.6$\mu \mathrm{m}$ latex spheres and a flow cytometer (Becton Dickinson FACSort) for 1.82- $\mu \mathrm{m}$ latex spheres. Chl $a$ was measured fluorometrically.

\section{Results and discussion}

Accumulation of freshly produced TEP in the surface lay$e r$-In all 10 experiments, TEP concentrations in the surface layer after $0.5-6 \mathrm{~h}$ were higher than those in the bottom layer, although samples were collected from ecologically varying conditions and experiments were conducted with different flocculation and settling intervals. Accumulation of TEP, calculated by the difference of TEP concentrations in surface and bottom layers and normalized by the average concentration, ranged from $13.3 \%$ to over $90 \%$ (Table 1). No significant relationship was observed, however, between the degree of accumulation of TEP in the surface layer and the measured characteristics of the sample, including sampling depth, Chl $a$, nutrient concentrations and TEP concentration, or flocculation period and settling time.

The average ascending velocity of TEP, $W_{\text {TEP }}$, was calculated from the increase of TEP concentration in the surface layer as

$$
W_{\mathrm{TEP}}=\frac{\left(C_{t}-C_{0}\right) V}{\pi r_{\mathrm{c}}^{2} C_{0} t}
$$

where $C_{t}$ and $C_{0}$ are concentrations of TEP $\left(\mu \mathrm{g} \mathrm{Xeq} \mathrm{L}^{-1}\right)$ in the surface layer at time $t$ and $0, V$ is the volume of the surface layer $\left(100 \mathrm{~cm}^{3}\right), r_{\mathrm{c}}$ is the radius of the settling column $(3.5 \mathrm{~cm})$, and $t$ is the time interval of experiments. Concentration, size, and density of TEP at time 0 were assumed homogeneous throughout the column. The calculated ascending velocity of particle-free TEP ranged from $4.85 \times$ $10^{-5} \mathrm{~cm} \mathrm{~s}^{-1}$ to $2.49 \times 10^{-4} \mathrm{~cm} \mathrm{~s}^{-1}$, with an average velocity of $1.6 \times 10^{-4} \mathrm{~cm} \mathrm{~s}^{-1}$ (Table 1 ).

The average density of TEP (Eq. 2) was then calculated with the ascending velocities obtained by Eq. 1 and Stokes' equation,

$$
W_{\mathrm{TEP}}=\frac{2}{9} \cdot \frac{g r_{\mathrm{TEP}}^{2}\left(\rho_{\mathrm{w}}-\rho_{\mathrm{TEP}}\right)}{\mu}
$$

where $r_{\text {TEP }}$ is the radius of TEP, $g$ is gravity, $\mu$ is the dynamic viscosity, and $\rho_{\mathrm{TEP}}$ and $\rho_{\mathrm{w}}$ are densities of TEP and the ambient seawater, respectively. TEP were assumed to be spherical with a uniform radius, and the Reynolds number was assumed to be $<1$. From Eqs. 1 and 2, the density of TEP can then be calculated (Eq. 3).

$$
\rho_{\mathrm{TEP}}=\rho_{\mathrm{w}}-\frac{9}{2} \frac{W_{\mathrm{TEP}} \mu}{g r_{\mathrm{TEP}}^{2}}=\rho_{\mathrm{w}}-\frac{9}{2} \frac{\mu}{g r_{\mathrm{TEP}}^{2}} \frac{\left(C_{t}-C_{0}\right) V}{\pi r_{\mathrm{c}}^{2} C_{0} t}
$$

With an average freshly generated TEP size of 3-4 $\mu \mathrm{m}$, determined microscopically, the calculated density of TEP ranged from 0.70 to $0.84 \mathrm{~g} \mathrm{~cm}^{-3}$. Density is one of the least known parameters of marine particles, and no direct measurements of TEP density have been reported to date, although the density of extracellular polymeric substances (EPS) from biofilm has been determined. Biofilm is produced by microbial cells attached to any submerged surface and consists of an EPS matrix and embedded organisms (Köster and Meyer-Reil 2002). The chemical and physical characteristics of EPS are similar to those of TEP (Passow 2002). The dry density of EPS ranges from 0.01 to $0.05 \mathrm{~g}$ $\mathrm{cm}^{-3}$ and bacterial extracellular polymers are known to be highly hydrated, $\sim 99 \%$ water by weight (Characklis and Gooksey 1983). Using the range of dry density of biofilm and a water content of $99 \%$ by weight, the hydrated biofilm density lies between 0.51 and $0.86 \mathrm{~g} \mathrm{~cm}^{-3}$. Our estimate of TEP density is within this range of EPS density. This result is also consistent with the observation that TEP cannot be enriched by centrifugation (Alldredge et al. 1993). 
Accumulation of TEP in the surface layer might also be explained by surface-active TEP being transported to the surface layer by diffusion, where they adhere to the airwater interface. The time scale $(\tau)$ necessary for the accumulation of TEP by passive diffusion is estimated by $\tau=$ $L^{2} / D$, where $L$ is a characteristic length and $D$ is the diffusion coefficient of TEP. In our experiment, $L$ was equal to the surface layer height of the settling column from the bottom $(2.6 \mathrm{~cm})$, and $D$ can be estimated by the molecular diffusion of salt $\left(1.5 \times 10^{-5} \mathrm{~cm}^{2} \mathrm{~s}^{-1}\right)$, which is most likely much higher than that of TEP. (TEP is much larger than salt molecules.) Because $\tau>5 \mathrm{~d}$, whereas TEP accumulated in the surface layer after only hours, it can be concluded that diffusion and trapping of TEP at the air-water interface did not contribute significantly to the observed accumulation of TEP during these experiments. This process might, however, be important in the ocean, where turbulence and convection is dominant. TEP are very sticky and possible trapping of bubbles, generated during experiments, can also cause TEP to ascend. Bubbles can be generated by photosynthesis and trapped in aggregates (Riebesell 1992); however, in our experiments, filtered seawater was used to produce TEP. Therefore, it is not likely that any bubbles were generated by organisms during TEP formation. Although "cavitation" by acceleration of liquid can produce bubbles, a flocculator, which we used in our experiments, was operated at a much slower than critical speed to produce bubbles. Also, we did not find bubbles during microscopic observation of newly produced TEP. Therefore, observed TEP accumulation in the surface layer was not caused by trapped bubbles in TEP. However, bubbles are ubiquitous in the upper ocean and trapping of bubbles by sticky TEP adds another means of upward transport of TEP.

Physical and chemical characteristics of TEP, and therefore their densities, are expected to vary spatially and temporally, depending on amount and characteristics of precursor dissolved organic carbon, strength of shear, and age of TEP. A marine polymer gel assembly from dissolved organic matter (DOM) showed the divalent binding (Chin et al. 1998). However, cation bridging was not significant for formation of microparticles from DOM in freshwater systems (Kerner et al. 2003). Phase transformation of TEP with time, collapse of the polymer network, and reduced hydration, can result in a dense, nonporous array, and therefore increase the densities of TEP. Density variation of TEP with space and time has important implications for biogeochemical cycle of carbon and other elements in the upper ocean and requires further investigations.

Upward flux of aggregates composed of TEP and latex spheres-In situ, TEP are commonly covered with bacteria and entangled with other living and nonliving particles, forming microaggregates of tens to hundreds of microns in size (Alldredge et al. 1993). The sinking behavior of microaggregates was studied in experiments 9 and 10 with the use of latex spheres with mean diameters of 45.6 and $1.82 \mu \mathrm{m}$ to mimic small solid particles. Concentrations of latex spheres used in these experiments lie within the range of cell numbers of diatoms and bacteria in the upper ocean.

Because 45.6- $\mu \mathrm{m}$ latex spheres have a Stokes' sinking
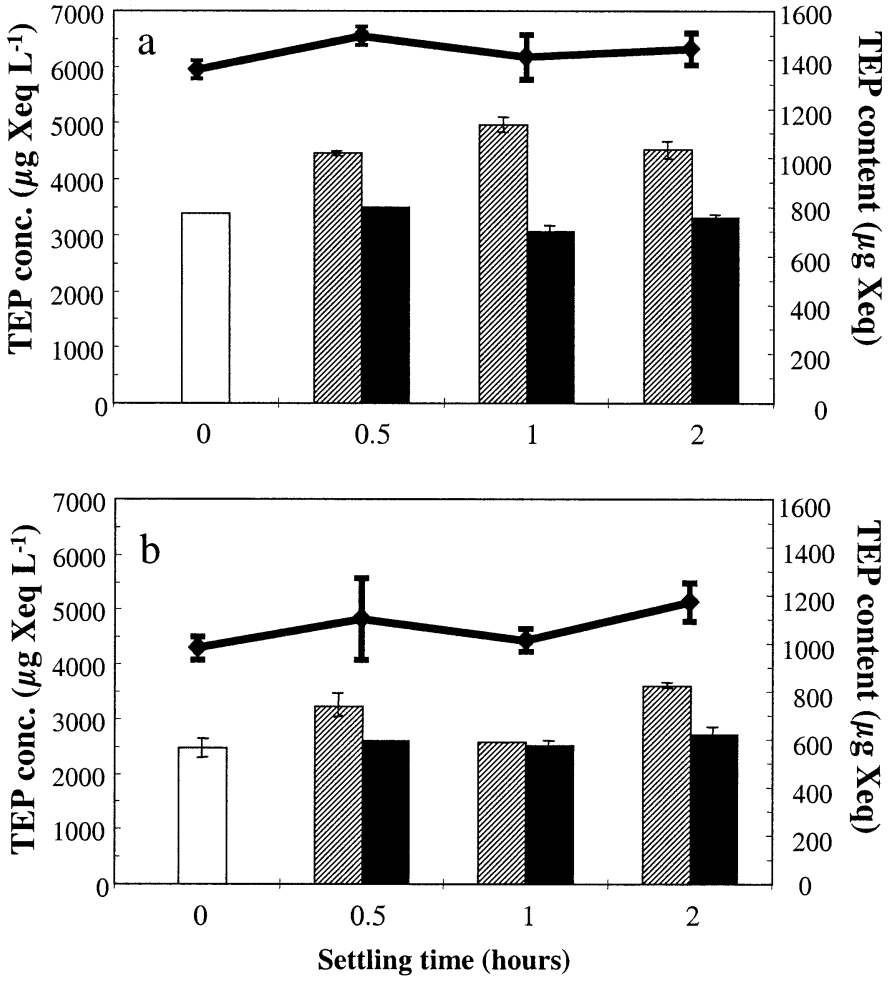

Fig. 1. Changes in the TEP concentration during (a) experiments 9 and (b) 10, in which the settling behavior of latex sphereTEP aggregates was investigated. TEP concentration in the surface $(0-2.6 \mathrm{~cm})$ and the bottom $(2.6-7.8 \mathrm{~cm})$ layers after settling intervals of $0,0.5,1$, and $2 \mathrm{~h}$ are shown. Results are averages of triplicate measurements and expressed as a microgram xanthan equiv-

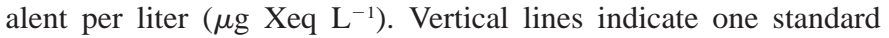
deviation. The total concentration of TEP in the entire settling column is shown on the right axis.

velocity of $2.94 \times 10^{-3} \mathrm{~cm} \mathrm{~s}^{-1}$, these larger latex spheres should - in the absence of TEP-settle out of the surface layer (100 ml, $2.6 \mathrm{~cm}$ deep) within $0.5 \mathrm{~h}$. The Stokes' velocity of $1.82-\mu \mathrm{m}$ spheres is $4.34 \times 10^{-6} \mathrm{~cm} \mathrm{~s}^{-1}$, so that the concentration of these smaller latex spheres should only decrease by $1.2 \%$ during a 2 -h experiment. Because aggregation between spheres increases their sinking velocity, these are conservative estimates.

Aggregates consisting of latex spheres and TEP, however, accumulated in the surface layer within half an hour during experiment 9 (Figs. 1, 2). The concentration of TEP in the surface layer was enriched by $24 \%$ after 30 min (Fig. 1). During the remainder of experiment 9 , TEP concentration in the surface layer increased further and remained significantly higher than in the bottom layer (Fig. 1). The total amount of TEP within the settling column remained constant, implying that TEP were neither formed nor lost during the experiment (Fig. 1). The concentration of $45.6-\mu \mathrm{m}$ latex spheres in the surface layer had also increased after $30 \mathrm{~min}$ and continued to rise during the entire settling period (Fig. $2 a$ ), while the concentration of spheres in the bottom layer 

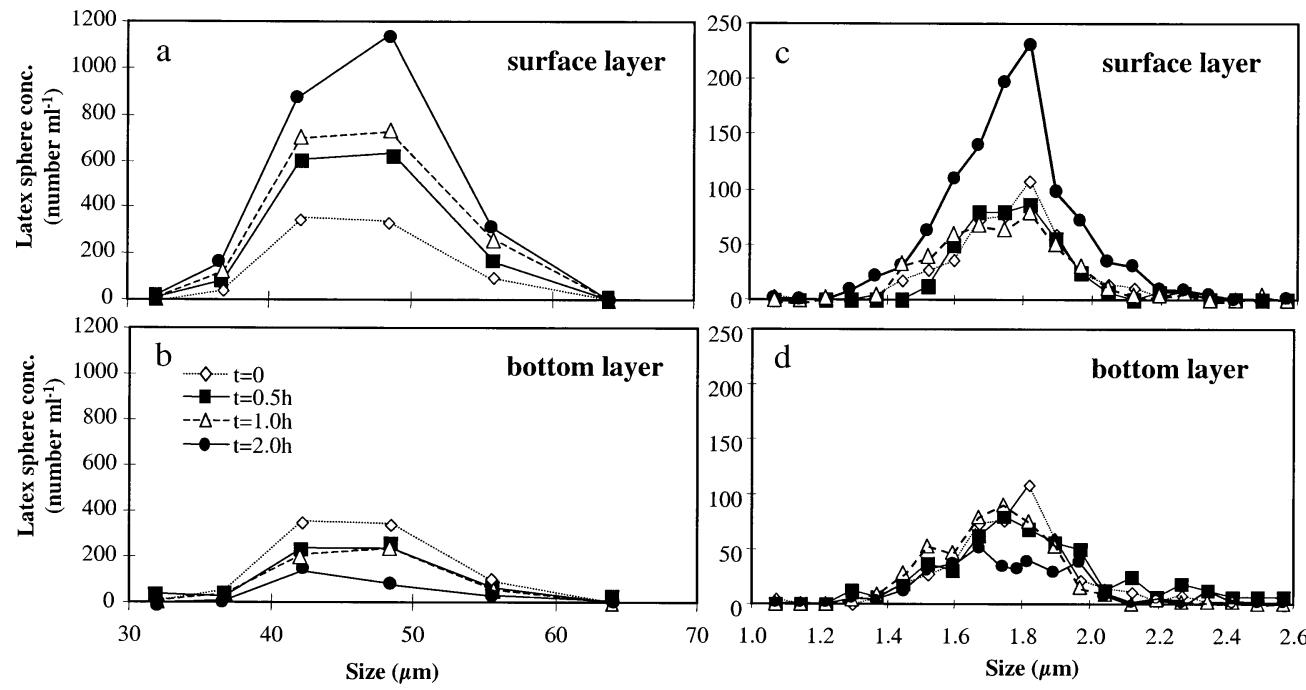

Fig. 2. Changes in the size frequency distribution of 45.6- $\mu \mathrm{m}$ latex spheres (a, b) and 1.82- $\mu \mathrm{m}$ latex spheres $(\mathrm{c}, \mathrm{d})$ in the surface and the bottom layers, respectively, at times $0,0.5,1$, and $2 \mathrm{~h}$.

decreased accordingly (Fig. 2b). These results suggest that the density of latex sphere-TEP aggregates were lighter than ambient water, resulting in their ascension.

Apparent ascending velocity of latex sphere-TEP aggregates $\left(W_{\mathrm{a}}\right)$ was calculated from the increase of latex spheres in the surface layer using Eq. 4, which is similar to Eq. 1. Concentrations of latex spheres (number $\mathrm{ml}^{-1}$ ) at times $t$ and 0 are denoted by $N_{t}$ and $N_{0}$.

$$
W_{\mathrm{A}}=\frac{\left(N_{t}-N_{0}\right) V}{\pi r_{\mathrm{c}}^{2} N_{0} t}
$$

Latex sphere-TEP aggregates were assumed to be distributed homogeneously at time 0 and to be identical at time $t$, with regard to size and number of latex spheres and, therefore, ascending velocity. The ascending velocity of latex sphere-TEP aggregates decreased from $1.08 \times 10^{-3} \mathrm{~cm} \mathrm{~s}^{-1}$ at $0.5 \mathrm{~h}$ to $7.09 \times 10^{-4} \mathrm{~cm} \mathrm{~s}^{-1}$ at $2 \mathrm{~h}$, with an average of $8.72 \times 10^{-4} \mathrm{~cm} \mathrm{~s}^{-1}$. The average ascending velocity of latex sphere-TEP aggregates calculated from changes in TEP concentration was in the same range, although somewhat lower $\left(2.2 \times 10^{-4} \mathrm{~cm} \mathrm{~s}^{-1}\right)$. The calculation, on the basis of changes in TEP, is considered less reliable because concentration changes of TEP were small compared with those of latex spheres; therefore, the analytical error was higher. The ascending velocity of latex sphere-TEP microaggregates was faster than that of particle-free TEP because aggregates were larger than TEP alone, and the effect of the change in size compensated for the effect of a change in density on ascension speed. The ascending velocity of latex sphere-TEP microaggregates decreased with time (on the basis of calculations of either latex spheres or TEP). This suggests that the latex sphere to TEP ratio of aggregates entering the surface layer increased with time. Consequently, the density of these microaggregates $\left(\rho_{\mathrm{A}}\right)$ increased over time, which in turn caused the decrease in the upward velocity of aggregates entering the surface layer.

In experiment 10 , in which $1.82-\mu \mathrm{m}$ latex spheres were added, TEP and latex spheres also accumulated in the sur- face layer, but less notably than in experiment 9 (Figs. 1b, $2 c, d)$. The difference in the concentration of latex spheres between the surface and bottom layer was only statistically significant after $2 \mathrm{~h}$ of settling, when the concentration of latex spheres in the surface layer was three times higher than in the bottom layer. The lower concentration of TEP and the lower concentration and sinking velocity of latex spheres during experiment 10 could explain the lack of a significant accumulation of TEP and latex spheres after 0.5 and $1 \mathrm{~h}$. Apparent ascending velocities calculated from changes in latex sphere and TEP concentrations after $2 \mathrm{~h}$ were $4.44 \times$ $10^{-4} \mathrm{~cm} \mathrm{~s}^{-1}$ and $3.00 \times 10^{-4} \mathrm{~cm} \mathrm{~s}^{-1}$, respectively. As in experiment 9, estimates of the ascending velocity of aggregates based on changes in latex spheres were more reliable than those based on changes in TEP.

Model-based evaluation of the effect of TEP on the vertical transport of solid particles-We have demonstrated that freshly produced, particle-free TEP ascend and that TEP can also transport latex spheres upward. Marine aggregates contain TEP, and incorporation of positively buoyant TEP into aggregates adds a new dimension to the concept of vertical transport of marine particles. We will evaluate the role of TEP in the flux of latex spheres with a simple model.

If the fraction of the aggregate volume that is occupied by TEP is $\alpha(\times 100 \%)$ and the fraction occupied by solid matter (e.g., latex spheres in our experiments), is $\beta$ $(\times 100 \%)$, then the density of the aggregates $\left(\rho_{\mathrm{A}}\right)$ can be expressed as

$$
\rho_{\mathrm{A}}=\alpha \rho_{\mathrm{TEP}}+\beta \rho_{\mathrm{s}}+(1-\alpha-\beta) \rho_{\mathrm{w}}
$$

with

$$
1 \geq \alpha+\beta
$$

where $\rho_{\mathrm{TEP}}, \rho_{\mathrm{s}}$, and $\rho_{\mathrm{w}}$ are densities of TEP, solid material, and interstitial water, respectively. When $\alpha+\beta=1$, aggregates are composed of only TEP and solid materials and no 


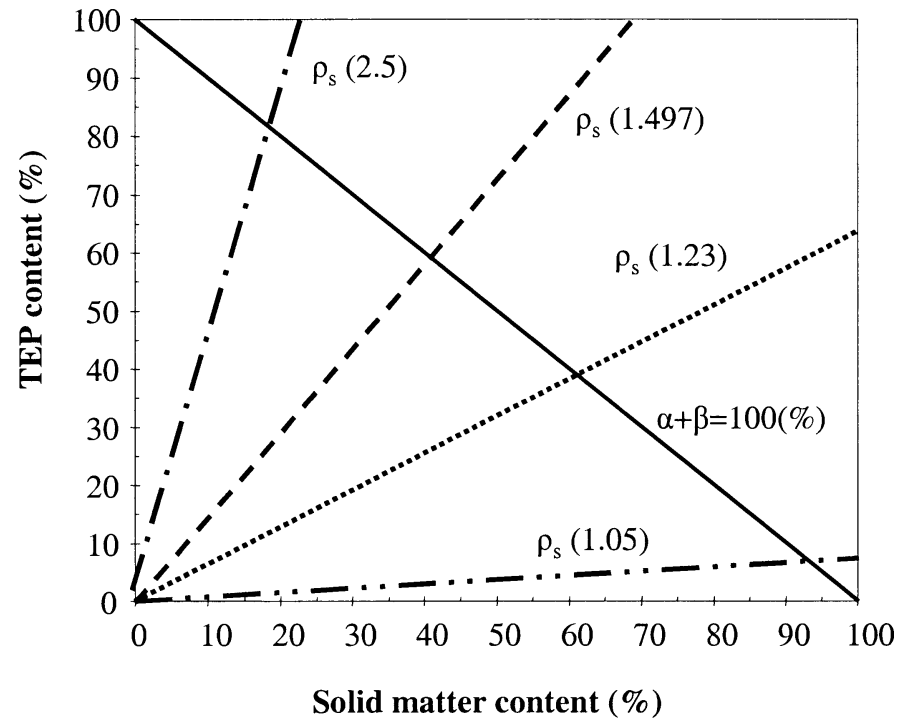

Fig. 3. Model results depicting the TEP volume fraction in aggregates $(\alpha)$, the TEP volume fraction in aggregates as a function of solid particle density $\rho_{\mathrm{s}}$, and solid particle volume fraction $(\beta)$ are illustrated. Each density line $\left(\rho_{\mathrm{s}}\right)$ indicates the relationship between $\alpha^{\prime}$ (the volume fraction of TEP for neutrally buoyant aggregates) and $\beta$ for various solid particle densities. The solid line shows $\alpha+\beta=1$ (i.e., where aggregates contain no interstitial water). The domain constrained by the left side of the solid line and above a specific density line describes conditions in which aggregates with solid particles of the respective density will ascend. The area left of the solid line and below the respective density line characterizes conditions in which aggregates sink.

interstitial water is included in aggregates. From Eq. 5, we derive Eq. 7.

$$
\alpha=\frac{\beta\left(\rho_{\mathrm{s}}-\rho_{\mathrm{w}}\right)+\left(\rho_{\mathrm{w}}-\rho_{\mathrm{A}}\right)}{\left(\rho_{\mathrm{w}}-\rho_{\mathrm{TEP}}\right)}
$$

When $\rho_{\mathrm{w}}-\rho_{\mathrm{A}}=0$, aggregates are neutrally buoyant and

$$
\alpha^{\prime}=\frac{\beta\left(\rho_{\mathrm{s}}-\rho_{\mathrm{w}}\right)}{\left(\rho_{\mathrm{w}}-\rho_{\mathrm{TEP}}\right)}
$$

where $\alpha^{\prime}$ is the volume fraction of TEP at neutral buoyancy of aggregates. The relationship between $\alpha$ and $\alpha^{\prime}$ provides a criterion for the vertical transport of aggregates; that is, when $\alpha>\alpha^{\prime}$, aggregates will ascend to the surface and when $\alpha<\alpha^{\prime}$, aggregates will settle. Figure 3 depicts the critical value of the volume fraction of TEP needed for aggregates to be neutrally buoyant $\left(\alpha^{\prime}\right)$ as a function of the solid matter volume fraction $(\beta)$ with various solid matter densities. The calculations are based on the average TEP density of $0.70 \mathrm{~g}$ $\mathrm{cm}^{-3}$ determined earlier and an interstitial water density of $1.026 \mathrm{~g} \mathrm{~cm}^{-3}$ (salinity 35 ; temperature $15^{\circ} \mathrm{C}$ ). When TEP and solid matter volume fractions in aggregates $(\alpha$ and $\beta$, respectively) are in the domain constrained by $\alpha+\beta \leq 1$ and when $\alpha>\alpha^{\prime}$, particles will ascend, whereas they will settle when $\alpha<\alpha^{\prime}$.

For solid particles with the same density as the latex spheres used in this study $\left(\rho_{\mathrm{s}}=1.05 \mathrm{~g} \mathrm{~cm}^{-3}\right)$, the critical volume ratio of TEP to solid matter calculated from Eq. 8 is $\alpha / \beta=\left(\rho_{\mathrm{s}}-\rho_{\mathrm{w}}\right) /\left(\rho_{\mathrm{w}}-\rho_{\mathrm{TEP}}\right)=0.074$. This means that if the TEP volume is larger than $7.4 \%$ of the solid matter volume, aggregates will ascend. For example, an aggregate consisting of $50 \%$ by volume latex spheres would ascend if the TEP volume fraction was larger than $3.7 \%$. Nothing is known about the porosity or TEP volume content of microaggregates. Visual inspections of microaggregations consisting of bacteria, TEP, and picodetritus suggest that these might easily contain 5-10\% TEP. Although volume fractions of TEP and porosity in aggregates need to be studied further, our study demonstrates that an appreciable number of such microaggregates could ascend at significant velocities under natural conditions.

Vertical transport of marine snow-sized aggregates-Direct measurements of the solid matter density of large aggregates $(>290 \mu \mathrm{m})$ range from 1.095 to $>1.497 \mathrm{~g} \mathrm{~cm}^{-3}$ in coastal waters, whereas solid matter density of large aggregates produced from a diatom culture $(>635 \mu \mathrm{m}$ in size $)$ ranges from 1.257 to $1.356 \mathrm{~g} \mathrm{~cm}^{-3}$ (Azetsu-Scott and Johnson 1992). A solid matter density of $\rho_{\mathrm{s}}=1.23 \mathrm{~g} \mathrm{~cm}^{-3}$ represents the wet density of euphausiid fecal pellets (Komar et al. 1981), and $\rho_{\mathrm{s}}=2.5 \mathrm{~g} \mathrm{~cm}^{-3}$ is equal to the density of quartz. When the density of solid particles enclosed in an aggregate is high, the volume ratio $\alpha / \beta$ must be larger for aggregates to be neutrally buoyant. For example, aggregates consisting of fecal pellets $\left(\rho_{\mathrm{s}}=1.23 \mathrm{~g} \mathrm{~cm}^{-3}\right)$ or quartz $\left(\rho_{\mathrm{s}}\right.$ $\left.=2.5 \mathrm{~g} \mathrm{~cm}^{-3}\right)$ must have respective TEP volume contents of 0.62 , or 4.52 times the solid matter volume for aggregates to be neutrally buoyant. That means an aggregate, consisting of $1 \%$ fecal pellets or quartz would be positively buoyant if the TEP content exceeded $0.62 \%$ or $4.52 \%$, respectively (Fig. 3). The solid particle volume of natural marine snowsized aggregates is $<10 \%$, commonly $<0.1 \%$ or even $<0.01 \%$ (Alldredge and Gotschalk 1988; Alldredge and Crocker 1995; Engel and Schartau 1999). The TEP content of marine snow-sized aggregates is difficult to measure, and few data exist. However, a variety of estimates suggests a TEP volume fraction in the range of $0.5-5 \%$ for natural aggregates (see review in Passow 2002) and larger volume fractions for mixed phytoplankton aggregates formed on the roller table (Engel et al. 2002). The respective volume fractions of solid matter, TEP, and interstitial water in natural marine snow-sized aggregates are thus in the range to potentially allow aggregates not only to sink, but also to be neutrally buoyant or ascend.

Average sinking velocities of large aggregates are in the range of $50-200 \mathrm{~m} \mathrm{~d}^{-1}$ and are mainly a function of size within the euphotic zone (Alldredge and Gotschalk 1988). Estimates from in situ photography, on the other hand, indicate that aggregates of the same size class exhibit a wide range of sinking velocities (Asper 1987; Diercks and Asper 1997). Large differences between the sinking velocities measured for individual aggregates and the average sinking velocities calculated from particle concentration and flux also indicate that sinking velocities of aggregates in any size class can vary widely (Shanks 2002). Here, we argue that any population of aggregates will most certainly consist of sinking, neutrally buoyant, and possibly ascending aggregates. Differences in the respective volume fractions of solid matter, TEP, and interstitial water could explain the large devi- 
ations from the average relationship between aggregate size and sinking velocity such as that observed for individual aggregates by Shanks (2002). The vertical transport of aggregates, specifically, the rate of ascent or settling, will be controlled by the interplay between TEP, ambient solid particles, and environmental factors. Moreover, the chemical structure and physical characteristics of TEP depend on biological and abiotic factors resulting in variable TEP densities in time and space, adding another component to the concept of particle flux.

Significance of TEP in biogeochemical cycles in the upper ocean-Individual TEP and TEP-rich microaggregates ascend at velocities as fast as $0.1-1 \mathrm{~m} \mathrm{~d}^{-1}$ to the ocean surface. Phytoplankton exudates can substantially reduce gas transfer rates at the interface between the water surface and the atmosphere, and it has been speculated that they could function as microlayer surfactants (Frew et al. 1990). TEP are very surface active (Mopper et al. 1995; Zhou et al. 1998), and a variety of trace substances are likely to be associated with TEP. TEP could hence be one of the sources for the sea surface microlayer (SSM), which is enriched in organic chemicals, microorganisms, nutrients, and trace metals (Hunter 1997; Zaitsev 1997; Zang et al. 1998). Rising TEP add a new mechanism for the production of the SSM, along with the previously suggested mechanisms, such as diffusion, turbulent mixing, bubble transport, direct atmospheric deposition of surfactants (Asher 1997), and photochemistry (Blough 1997). Once TEP reach the air-sea interface and are incorporated into the SSM, TEP will be decomposed by an abundant heterotrophic community, as well as by photodegradation, or will be exported to the atmosphere as aerosol particles.

Moreover, rising TEP will affect flux of solid particles in the ocean. Differential settling of particles increases their collision frequency and thus promotes their aggregation. Consequently, positively buoyant TEP or TEP-rich aggregates encounter settling or suspended solid particles with an increased collision frequency. Enhanced aggregation of solid particles with ascending TEP-rich aggregates changes the density of the aggregates. As the ratio of TEP and solid matter within aggregates reaches the critical value, ascending will slow and stop, and then aggregates will start settling. Continued aggregation and disaggregation will again alter the ratio between TEP and solid particles, affecting the sinking velocity. Inclusion of buoyant TEP in aggregates can regulate the export flux of particulate organic carbon (POC). Kiørboe et al. (1998) showed low vertical flux during the diatom bloom, despite intensive aggregate formation, in the upwelling region with high TEP concentration. Vertical flux of POC is often estimated with the use of tracers such as ${ }^{234} \mathrm{Th}$. A recent study by Santschi et al. (2003) showed that surface-active polysaccharides, which TEP are composed of, are responsible for ${ }^{234} \mathrm{Th}$ binding. Upward flux of TEP, therefore, requires additional evaluation of the biological pump estimated by ${ }^{234} \mathrm{Th}$.

Even if the TEP content in aggregates is not sufficient to initiate upward transport to the very surface of the ocean, buoyant TEP in aggregates will prolong the residence time of solid particles in the surface ocean. Therewith, TEP af- fects the cycling of carbon, reactive elements adsorbed onto aggregates, and nutrients in the upper layer of the ocean.

\section{References}

Alldredge, A. L., And K. M. CRocker. 1995. Why do sinking mucilage aggregates accumulate in the water column? Sci. Total Environ. 165: 15-22.

Alldredge, A. L., AND C. Gotschalk. 1988. In situ settling behavior of marine snow. Limnol. Oceanogr. 33: 339-351.

Alldredge, A. L., U. PAssow, ANd B. E. Logan. 1993. The abundance and significance of a class of large, transparent organic particles in the ocean. Deep-Sea Res. I 40: 1131-1140.

Asher, W. 1997. The sea-surface microlayer and its effect on global air-sea gas transfer, p. 251-286. In P. S. Liss and R. A. Duce [eds.], The sea surface and global change. Cambridge Press.

AsPER, V. L. 1987. Measuring the flux and sinking speed of marine snow aggregates. Deep-Sea Res. 34: 1-17.

AzETSU-ScotT, K., AND B. D. Johnson. 1992. Measuring physical characteristics of particles: A new method of simultaneous measurement for size, settling velocity and density of constituent matter. Deep-Sea Res. 39: 1057-1066.

Blough, N. V. 1997. Photochemistry in the sea-surface microlayer, p. 383-424. In P. S. Liss and R. A. Duce [eds.], The sea surface and global change. Cambridge Press.

Characklis, W. G., and K. E. Gooksey. 1983. Biofilms and microbial fouling. Adv. Appl. Microbiol. 29: 93-138.

Chin, W.-C., M. V. Orellana, ANd P. Verdugo. 1998. Spontaneous assmbly of marine dissolved organic matter into polymer gels. Nature 39: 568-572.

Culver, M. E., AND W. O. SMith. 1989. Effects of environmental variation on sinking rates of marine phytoplankton. J. Phycol. 25: 262-270.

Dam, H. G., And D. T. Drapeau. 1995. Coagulation efficiency, organic-matter glues, and the dynamics of particles during a phytoplankton bloom in a mesocosm study. Deep-Sea Res. II 42: 111-123.

DierCKS, A. R., AND V. L. AsPer. 1997. In situ settling speeds of marine snow aggregates below the mixed layer: Black Sea and Gulf of Mexico. Deep-Sea Res. I 44: 385-398.

ENGEL, A. 2000. The role of transparent exopolymer particles (TEP) in the increase in apparent particle stickiness (alpha) during the decline of a diatom bloom. J. Plankton Res. 22: 485-497.

Engel, A., AND M. Schartau. 1999. Influence of transparent exopolymer particles (TEP) on sinking velocity of Nitzschia closterium aggregates. Mar. Ecol. Prog. Ser. 182: 69-76.

Engel, A., M. MeyerhöFer, AND K. Von BröCKel. 2002. Chemical and biological composition of suspended particles and aggregates in the Baltic Sea in summer. 1999. Estuar. Coast. Shelf Sci. 55: 729-741.

Frew, N. M., J. C. Goldman, M. R. Dennett, and A. S. Johnson. 1990. Impact of phytoplankton-generated surfactants on airsea gas exchange. J. Geophs. Res. 95: 3337-3352.

Hunter, K. A. 1997. Chemistry of the sea-surface microlayer, p. 287-320. In P. S. Liss, R. A. Duce [eds.], The sea surface and global change. Cambridge Press.

JACKSON, G. A. 1995. TEP and coagulation during a mesocosm experiment. Deep-Sea Res. II 42: 215-222.

Kerner, M., H. Hohenberg, S. Ertl, M. Reckerman, And A. SPITZY. 2003. Self-organization of dissolved organic matter to micelle-like microparticles in river water. Nature 422: 150 154.

Kiørboe, T., R. Tiselius, B. Mitchell-Innes, J. L. S. Hansen, A. W. VISSER, AND X. MARI. 1998. Intensive aggregate formation 
with low vertical flux during an upwelling-induced diatom bloom. Limnol. Oceanogr. 43: 104-116.

KnAuER, G. 1991. Determination of mass flux, inorganic and organic mass flux in rapidly sinking particles, p. 79-83. In D. C. Hurd and D. W. Spencer [eds.], Marine particles: Analysis and characterization. V. 63. American Geophysical Union.

Komar, P. D., A. P. Morse, And L. F. Small. 1981. An analysis of sinking rates of natural copepod and euphausiid fecal pellets. Limnol. Oceanogr. 26: 172-180.

Köster, M., AND L. A. Meyer-ReIL. 2002. Ecology of marine microbial biofilms, p. 1081-1089. In G. Bitton [ed.], The encyclopedia of environmental microbiology. Wiley.

Logan, B. E., U. Passow, A. L. Alldredge, H.-P. Grossart, And M. SimON. 1995. Rapid formation and sedimentation of large aggregates is predictable from coagulation rates (half-lives) of transparent exopolymer particles (TEP). Deep-Sea Res. II 42: 203-214.

Macintyre, S., A. L. Alldredge, and C. C. Gotschalk. 1995. Accumulation of marine snow at density discontinuities in the water column. Limnol. Oceanogr. 40: 449-468.

Mopper, K., J. Zhou, K. S. Ramana, U. Passow, H. G. Dam, and D. T. DRAPEAU. 1995. The role of surface-active carbohydrates in the flocculation of a diatom bloom in a mesocosm. DeepSea Res. II 42: 47-73.

PAssow, U. 2000. Formation of transparent exopolymer particles, TEP, from dissolved precursor material. Mar. Ecol. Prog. Ser. 192: $1-11$

. 2002. Transparent exopolymer particles (TEP) in aquatic environments. Prog. Oceanogr. 55: 287-333.

Passow, U., AND A. L. Alldredge. 1994. Distribution, size, and bacterial colonization of transparent exopolymer particles (TEP) in the ocean. Mar. Ecol. Prog. Ser. 113: 185-198.

, AND —. 1995. A dye-binding assay for the spectrophotometric measurement of transparent exopolymer particles (TEP). Limnol. Oceanogr. 40: 1326-1335.
- - - AND B. E. LogAN. 1994. The role of particulate carbohydrate exudates in the flocculation of diatom blooms. Deep-Sea Res. I 41: 335-357.

, R. F. Shipe, A. Murray, D. K. PaK, M. A. Brzezinski, AND A. L. Alldredge. 2001. Origin of transparent exopolymer particles (TEP) and their role in the sedimentation of particulate matter. Cont. Shelf Res. 21: 327-346.

RIEBESELL, U. 1992. The formation of large marine snow and its sustained residence in surface waters. Limnol. Oceanogr. 37: 63-76.

Santschi, P. H., C.-C. Hung, G. Schults, N. Alvarado-Quiroz, L. Guo, J. Pinckney, And I. Walsh. 2003. Control of acid polysaccaride production and ${ }^{234} \mathrm{Th}$ and POC export fluxes by marine organisms. Geophys. Res. Lett. 30: doi:10.1029/ 2002 GL016046.

SHANKs, A. L. 2002. The abundance, vertical flux, and still-water and apparent sinking rates of marine snow in a shallow coastal water column. Cont. Shelf Res. 22: 2045-2064.

Simon, M., A. L. Alldredge, AND F. AzAM. 1990. Bacterial carbon dynamics on marine snow. Mar. Ecol. Prog. Ser. 65: 205-211.

Zaitsev, V. 1997. Newston of seas and oceans. In P. S. Liss and R. A. Duce [eds.], The sea surface and global change. Cambridge Press.

ZANG, Z., L. LiU, Z. Wu, J. Li, AND H. Ding. 1998. Physicochemical studies of the sea surface microlayer. J. Colloid Interface Sci. 204: 294-299.

Zhou, J., K. Mopper, AND U. PAssow. 1998. The role of surfaceactive carbohydrates in the formation of transparent exopolymer particles by bubble adsorption of seawater. Limnol. Oceanogr. 43: 1860-1871.

Received: 18 July 2003

Accepted: 5 January 2004

Amended: 9 January 2004 